\title{
Between conventionalization and civic agriculture: Emerging trends in the Chilean agroecological movement
}

\author{
Beatriz Cid-Aguayo ${ }^{a}$
}

Submitted 28 January 2011 / Accepted 7 April 2011 / Published online 27 May 2011

Citation: Cid-Aguayo, B. (2011).Between conventionalization and civic agriculture: Emerging trends in the Chilean agroecological movement. Journal of Agriculture, Food Systems, and Community Development, 1(3), 53-66. http://dx.doi.org/10.5304/jafscd.2011.013.010

Copyright (C) 2011 by New Leaf Associates, Inc.

\begin{abstract}
Chile has played a relevant role in neoliberal global food production since the 1980s, using the motto "Chile: An Agro-food Power." Thus, it is relevant to enquire about the exercise of individual and collective citizenship on the part of agricultural producers who attempt to challenge - or at least make a difference — within this dominant economic and productive model. This paper explores the development and current state of the agroecological movement in Chile as an expression of civic agriculture representing a Polanyian countermovement developed by diverse actors against the dominant discourse and practices of the "Chilean agro-food power." Performing a discourse analysis of interviews with agroecological producers in the Bío-Bío region of Chile, the paper discusses the limits of the literature with respect to conventionalization and bifurcation processes for the analysis of the Global South in particular. The paper shows
\end{abstract}

\footnotetext{
a Departamento de Sociología y Antropología, Facultad de Ciencias Sociales, Universidad de Concepción, Barrio Universitario s/n, Concepción, Chile; tel. (56 - 41) 2203038; fax (56 - 41) 2215860; beatrizcid@udec.cl
}

the hybrid and intertwined economic, productive, and political practices of agroecological peasants and organic farmers.

\section{Keywords}

agroecology, Chile, citizenship, civic agriculture, conventionalization, organic, Polanyi

\section{Introduction}

Since the 1980s, Chile has played a relevant role in global food production, particularly in the niche markets of fresh produce (especially off-season Mediterranean fruit for the North American market), premium wine, and Atlantic salmon, through aggressive modernization of the agrarian sector under a neoliberal, competitive-advantages, exportoriented development model. Moreover, during the last decade the Chilean government explicitly promoted the motto "Chile: An Agro-food Power" as a strategic guideline for its agricultural and rural policies. The Chilean strategy has involved a combination of massive international investment by agro-food corporations, monocultures, overuse of agrochemicals, seasonal labor, and an uneasy relationship with peasants and farmers. Thus, it is rele- 
vant to enquire as to the exercise of individual and collective citizenship on the part of agricultural producers who attempt to challenge - or at least make a difference - within this dominant economic and productive model. In more traditional words, this study explores several Polanyian countermovements (Polanyi, 2001) by which the active society attempts to re-embed the global selfregulating food market, perceived as dangerous and expanding, within social, environmental, and local controls.

This paper relies on a qualitative study that explores the development and current state of the agroecological movement (or, as we will see, movements) in the Bío-Bío region, in the centersouth of Chile (map below). Home to half of all Chilean agroecological production, the Bío-Bío region offers an illustrative case of a countermovement in the context of successful, hegemonic, neoliberal food production in the Global South. Despite evidence of conventionalization trends among bigger farmers, other behaviors can be seen that preserve some essential agroecological practices and constitute exercises of civic agriculture as an expression of several countermovements developed by diverse actors against the dominant discourse and practices of the Chilean agro-food power. This paper addresses the debate over the processes of conventionalization and bifurcation described in the literature as well as the possibility that agroecological production could constitute an exercise in environmental citizenship. Herein, small and medium-sized Chilean agroecological producers are shown to combine strategically the conventionalized and nonconventionalized practices, widely described in the literature, reported to separate these two branches of the agroecological movement. Whereas conventionalized practices are oriented to external and domestic markets and

\section{Map 1. Map of Chile and the Bío-Bío Region}

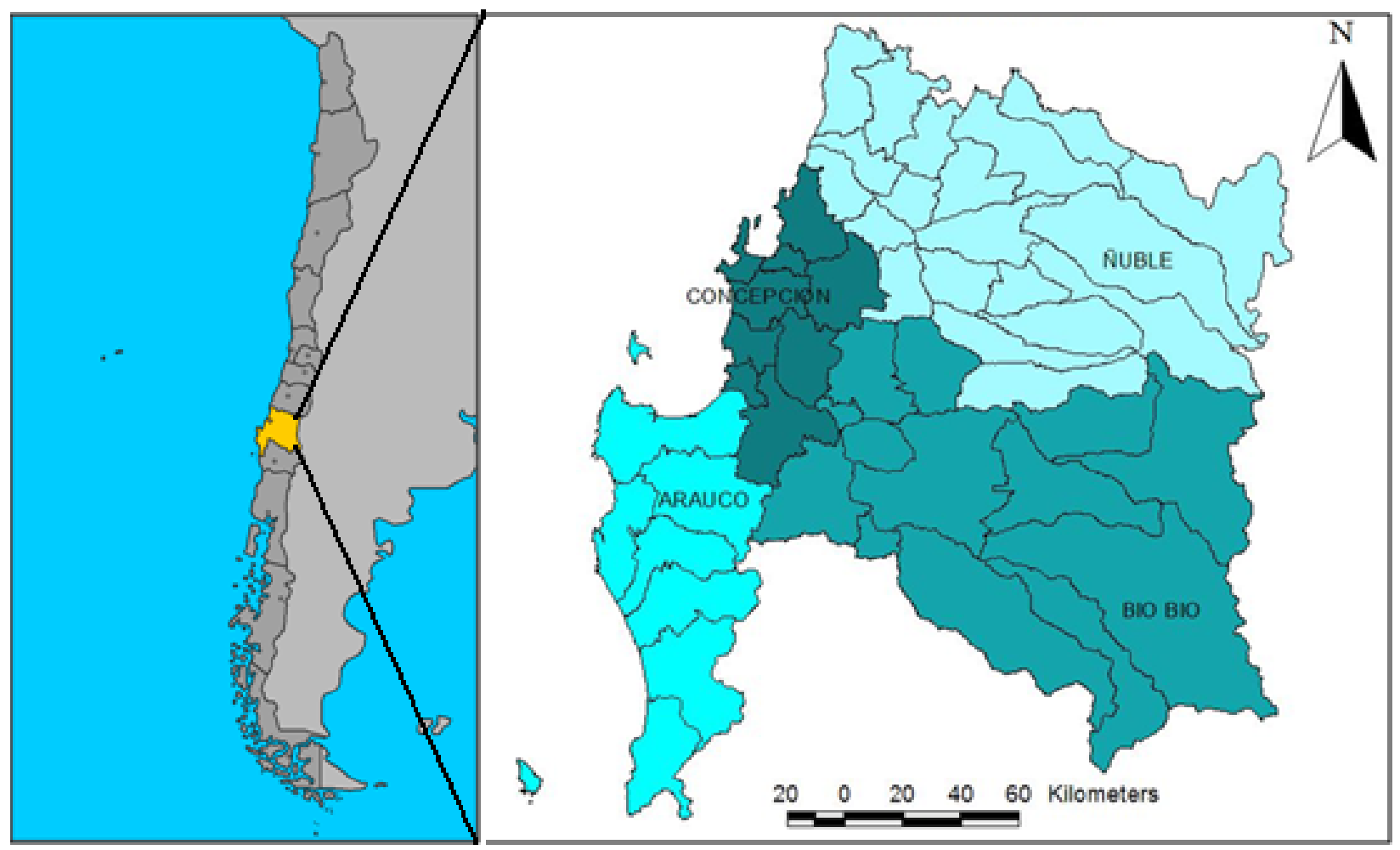

Chilean Map 1985-2007 by Lic. Octavio Rojas. Source: Academia de Ciencias Luventicus - Región del Bío Bío). Retrieved from http://www.luventicus.org/mapas/chile1985-2007/biobio.html 
useful for recapitalizing production, nonconventionalized practices are oriented to household consumption and the local market. Thus, to some extent, the exercise of environmental citizenship through the practice of civic agriculture (DeLind, 2002; Lyson, 2004) becomes articulated with more commercial practices oriented toward domestic and external markets.

\section{Agroecology, Conventionalization, and Civic Agriculture}

Critics argue that corporate agro-food globalization has been harmful to both the livelihood of food producers and the well-being of consumers (Barndt, 2002; FitzSimmons, 1997; Friedmann, 1994; Kneen, 1999). Such problems are addressed through countertrends that attempt to build economic and political alliances among suppliers, farmers, retailers, workers, and consumers, establishing self-reliant food networks based on elements of trust and cooperation to narrow the metabolic rifts associated with global food production and constrain the power of food corporations (Jarosz \& Qazi, 2000). The broad range of alternatives proposed to combat these dominant practices fall within the political categories of agroecology and food sovereignty (Altieri, 1998; Leahy, 2004). These proposals go beyond reforming the farming system in an attempt to transform the whole society: "A radical transformation of agriculture is needed, one guided by the notion that ecological change cannot be promoted without comparable changes in the social, political, cultural and economic arenas that also constrain agriculture" (Altieri, 1998, p. 4). All these proposals can be analyzed under Polanyi's perspective, who observes the devastating impacts that trends toward selfregulated markets of land, labor, and finance have on the fate of communities and nature; and that those tendencies are always accompanied by civic attempts to re-embed social controls on the market. In this sense, the agroecological movement is part of a large attempt by the Polanyian "active society" to establish some control over a socially and environmentally blind, neoliberal, economic logic.

The organic market and the organic certification process are both global-scale initiatives to re- embed (Polanyi, 2001) the global logic of food production into formalized structures of control in order to protect the environment and promote the well-being of farmers and consumers. The organic movement brings together different groups of actors - consumer organizations, environmental and social justice groups, and producer associations — in order to mobilize the consumer's willingness to pay according to environmental and social ends (Bacon, 2005). Organic certification is a selfregulatory, voluntary certification system that sets standards for recycling waste, reducing water pollution, using chemical inputs, and improving soil quality, offering price premiums to producers complying with the established standards (Muradian \& Pelupessy, 2005) to create a healthier, more sustainable agro-food system (Raynolds, 2000). Certification systems were initially encouraged by organic farmers and, to some extent, by merchants involved in the organic food market as a way to protect their market from fraud and to be able to guarantee the authenticity of the organic label (González \& Nigh, 2005; Raynolds, 2003). Although the international market for organic products has grown impressively in recent years, its scope is still limited. In this sense, Raynolds (2000) argues that the success of the organic market is best judged in terms of its ability to challenge the abstract capitalist relations that fuel exploitation in the global agro-food system as a form of political counterpower.

The economic discussion of organic production has been articulated with the political question of environmental citizenship, mostly in relation to consumption. The consumption of agroecological products has been widely conceptualized as an exercise of environmental citizenship on two grounds: first, responsible citizens display environmental ethics when performing sustainable consumption (Seyfang, 2005, 2006), and second, to eat well is included among the environmental rights (Dowler, 2008; Kojima, 2010). This form of citizenship has the advantage of transcending public/private differentiation, readdressing the feminist idea that personal and family options are deeply political. On the other hand, using consumption as a form of citizenship presents several problems, 
particularly the difficulty of distinguishing between narrow self-interest and actual concerns about the political economy of the production process and the desire to protect rural landscape and local economies (DeLind \& Bingen, 2008). Moreover, consumers choosing agroecological products in convenience stores displace their political concern onto others, expecting that while they only buy, the actual producers would exercise the political option of performing agroecological production.

The sphere of production has been less addressed in the citizenship debate; thus, whereas responsible consumption is considered to be civic, organic production is seen mostly as a personal option or even a business exercise. In fact, the discussion about the site of production has been largely dominated by certification regimes and the conventionalization debate, such that organic production appears to be driven mostly by business logic with minimal ecological criteria rather than by agroecological concerns.

According to the hypotheses of conventionalization and bifurcation in the literature (Gómez Tovar, Martin, Angel Gómez Cruz, \& Mutersbaugh, 2005; Raynolds, 2003), organic farmers entering into market competition under the logic of certification regimes split into two distinct groups. These hypotheses present the formalization of organic certification regimes as having denaturalized the agroecological principles that originally inspired the organic movement. Thus, conventionalized farmers are displacing movement-oriented farmers who emphasize distinct farming styles, crop choices, farm size, organizational structures, and personal relations. Such conventionalized producers apply minimal agroecological criteria and support the formalization of organic agriculture and its opening to corporate capital and agribusiness interests. In other words, conventionalized organic farmers are those whose practices no long represent a real departure from conventional agriculture and who are increasingly seen as conventional themselves. This bifurcation is reflected in the definition of certification regimes: despite the historical commitment of the organic movement to domestic and civic values (rooted in personal trust, diversity, and social justice), certification regimes enforce industrial and commercial quality conventions based on efficiency, standardization, bureaucratization, and price competitiveness (Raynolds, 2003).

The conventionalized organic certification regimes have been criticized on several grounds. First, they are accused of being top-down in nature, meaning that current organic standards are organized according to the demands of first-world consumer interests and imposed "from the top down" by certification agencies and intermediaries with little or no farmer participation (Gonzalez \& Nigh, 2005). In this sense, the progressive drive of what was originally an alternative trade has been lost because the purchasing practices of self-interested, wealthy consumers have been permitted to guide the movement. This top-down process undermines the original democratic basis of the organic movement and strengthens the subordination of Southern producers to the dictates of Northern consumers (Raynolds, 2000).

A second critique of conventionalization processes is that the logic and structure of certification regimes and the market structure of organic products tend to benefit large, capitalized farmers more than small ones. This is because the farmers have to pay for the certification process and the bureaucratic requirements for said certification have increased, favoring large farmers and agribusiness-style organic cultivation. Extensive farm-level records are burdensome for semi-illiterate farmers in Global South countries, and farm inspections carried out by foreign agencies - are expensive for isolated farmers. Large producers, on the other hand, have scale economies within the same of certification process; for example, the plots to be certified are more homogenous and more accessible. Thus, the process of organic certification tends to reinforce the advantaged position of large producers, constituting a new form of network governance that serves to reproduce and accentuate existing economic inequalities (Gómez Tovar, et al., 2005; Raynolds, 2003).

A third issue for critics is that of the market structure. Organic certification complicates the distinc- 
tion between products developed using minimally certified organic criteria and products from smallholders. Despite having completely different cost structures, the two products must compete for portions of the same market share. A thorough accounting of the political economy is obscured by the process. For example, although organic agribusiness production respects agrochemical and soil management standards, it is a fully capitalist enterprise that probably maintains conventional labor practices, contract farming strategies, and minimal on-farm biodiversity, all of which contrast completely with the productive structure of movementoriented producers or, more dramatically, with smallholders and peasant producers (Gómez Tovar, et al., 2005; Klonsky, 2000). Moreover, agribusinesses have the power to undermine existing committed producers through price competition (Guthman, 2004a).

Fourth, conventionalism has been criticized because the price premiums associated with organic certification have attracted corporate interests to organic production, leading to minimal practices that rely on a soft rather than a radical definition of organic (Goodman, 2005). This subverts the distinctiveness of organic farming as it permits high levels of intensification, bad labor practices, and few traditional activities such as crop rotation and intercropping. It may also contribute to lower standards due to the huge influence of agrobusinesses on the definition and manipulation of the processes of certification (Guthman, 2004a, 2004b). This issue leads toward conventionalization of the label, blurring its original radical nature. According to Buck, Getz, and Guthman (1997) and Goodman (2005), most conventionalized producers embrace a minimal and also cynical market-oriented definition of organic.

In short, the conventionalization and bifurcation trend described in the literature comes to several fatalistic conclusions that deny the possibility of a market-oriented farmer engaging in meaningful agroecological practices and leave politically minded consumers with the dilemma of choosing between local, super-small-scale agroecological producers (probably not able to satisfy the total local demand of urban centers), or ecologically blind agro-food corporations. Dissatisfied with this fatalistic and dualistic conclusion, and looking for a more conceptually complex approach (Rosin \& Campbell, 2008) capable of accounting for the nonlinear trajectories of alternative food chains (Pratt, 2009), I felt it was necessary to readdress agroecological and organic farming as a civic exercise. Using the concept of civic agriculture (DeLind, 2002; Lyson, 2000), this paper attempts to show that, agroecological production - as practiced by several different kinds of farmers - is not only a business option but also a true exercise of ecological citizenship. Moreover, in the Global South, it would be more fruitful to acknowledge those attempts to promote and deepen citizenship rather than to search for option for conventionalization on small and medium-sized farmers that would marginalize them from a deeper agroecological movement.

In civic agriculture, food and agricultural practices are organized according to the needs of farmers, consumers, and the local rural economies. It is an explicitly political attempt to make a difference between civic agriculture and industrially modeled, corporately controlled agriculture, putting the emphasis "on agriculture as a civic, as opposed to a purely economic issue" (DeLind, 2002, p. 217). In other words, "the imperative to earn a profit is filtered through a set of cooperative and mutually supporting social relations" (Lyson, 2004, p. 92). In this sense, civic agriculture corresponds explicitly to a Polanyian countertrend of re-embedding and relocalizing globalized and commoditized agriculture.

At least three kinds of Polanyian embeddednesss can be seen in particular. The first embeddedness is on nature: Civic agriculture rests on an "ecological" paradigm (Lyson, 2004) that attempts to connect with sociobiological processes that are geographically and historically localized. The second embeddedness is on place, which is a specifically effort to "relocalize" the food systems (DeLind, 2002). This place embeddedness has several dimensions: (a) in building a locally organized system of food production characterized by networks 
of producers, local resources, local markets and consumers, civic agriculture is seen as an integral part of rural communities, not merely as a producer of commodities; (b) it focuses on varieties and products that are often unique to a particular region or locality; and (c) it relies on indigenous and site-specific knowledge away from standardized production techniques (Lyson, 2004). Finally, civic agriculture is characterized by embeddedness in a food community that attempts to create new kinds of social relations of work and consumption around food. In terms of work, this means more labor- and land-intensive modes of production rather than capital-intensive ones. This raises questions about responsibility, reciprocity, and accountability of the working process. In terms of consumption, this means an attempt to forge direct market links between producers and consumers, rather than indirect links through middlemen (wholesalers, brokers, processors, etc.) (Lyson \& Guptill, 2004).

In sum, civic agriculture not only moves away from a strictly mechanistic focus on production and economic efficiency, but also moves toward food and farming systems responsive to particular ecological and socioeconomic contexts. As these practices are important for the relationship between people and the fate of the place in which they live, civic agriculture constitutes an exercise in the promotion of citizenship and environmentalism in rural settings (DeLind, 2002). This then means that farms cannot be considered to be practicing civic agriculture if they produce only for the export market, rely on nonlocal hired labor, engage in bad labor practices and large-scale contract farming, sell only to large food corporations, and are large-scale, absentee-owned or industrial farms.

This paper specifically examines several branches of the agroecological movement in Chile, particularly in the Bío-Bío region, home to half of all Chilean organic production. Despite evidence of conventionalization trends among larger farmers, it is necessary to consider several other behaviors that preserve some essential agroecological practices and constitute exercises of civic agriculture.

\section{Agroecology and Organic Agriculture in the Bío-Bío Region}

The Bío-Bío region is in south-central Chile (36 46'22"S) and has a Mediterranean climate. The area is irrigated by several rivers, and it is a traditional area for medium- and smallholders whose land is dedicated mostly to wheat, cattle, and sugarbeet production and small bulk wineries. In fact, the large haciendas that characterized the Chilean countryside until the first half of the twentieth century were never consolidated in this area.

Even today, the Agrarian Census shows predominantly small holdings, with $48.6 \%$ occupying fewer than 5 hectares (12.4 acres) and $64.9 \%$ set on fewer than 10 hectares (24.7 acres). In the last 20 years and in the context of an export-oriented economy, forestry and the paper industry have encroached on the area. During this time, 1,330,163 hectares $(3,286,904$ acres $)$ of land used largely for wheat and sugar-beet production have been covered by forestry plantations (Censo Agropecuario, 20062007). This has meant both a displacement of peasant agriculture and increasing conflicts over the use of water resources and the spread of agrochemicals.

A countermovement to this tendency in the BíoBío region has become the center of the Chilean agroecological movement. Three of the main national organizations promoting agroecology (Center of Education in Technology (CET) Yumbel, CET Sur, and Inia Quilamapu) are located in the region, as are most Chilean agroecological producers, including around 1,000 certified organic farms (both individual and cooperative ones), or half of all Chilean certified organic producers. In addition, the main certifying firm that operates in Chile, the German company Bío Control System Eco Guarantee (BCS), is headquartered in the city of Chillán, in the Bío-Bío region. Along with these certified producers, a group of noncertified, smallscale, agroecological producers, in both urban and rural locations, has developed, thanks to the demonstrative effect of the promoter institutions. This concentration seems to be related to the model provided by three large pioneer producers that have been farming organically since the 1970s. 
Motivated by my own sympathies with the agroecological movement and intrigued by its development, I developed an explorative qualitative study to find and describe the different actors in the Chilean agroecological production scene. Due to this explorative character, I used a snowball sample technique, starting with a couple of personal contacts. This led me to conduct 23 in-depth interviews and five focus groups. At the end of this stage, I had interviewed all the leaders and directors from formal and informal organizations of agroecological and organic producers, representatives of the certifying companies, local government officials linked to organic regulations, as well as a small sample of producers from each organization. Discourse analysis techniques, with a focus on the critical analysis of the text and context of the recorded interviews, were used. In addition, and as a part of a course assignment, sociology undergraduate students developed several ethnographic research projects within some of these organizations. During this process and due to my own motivations, I became progressively involved in the movement, and the study acquired a more participatory action research character. In fact, I organized an agroecological workshop in 2010, and I was invited to a second workshop in 2011.

Following analysis of the snowball sample interviews, I found that three distinct branches of the agroecological movement are present in the BíoBío region. The first branch is organized around the Agrupación de Agricultura Orgánica de Chile (Organic Agricultural Group of Chile, or AAOCH) and Bío-Bío Orgánico (Bío-Bío Organic). These organizations have similar and overlapping constituencies, mainly medium-sized farmers with a certain level of capitalization. Their production, which is mostly certified, is oriented to niche markets for high-end domestic consumption or the export market. The second branch of movement consists of a cluster of peasant federations, urban agriculture organizations, supporting foundations, and nongovernmental organizations (NGOs) that have turned to agroecological practices as a way to lower the cost of household food production, improve diets, and diversify family income through participation in informal local food markets.
Finally, the third agroecological branch is made up of the neo-rural, upper-class permaculture movement organized around the Instituto Chileno de Permacultura (Chilean Permaculture Institute, ICP) and the Granja Agroecológica El Manzano (Apple Tree Agroecological Farm). These groups embrace agroecology as part of their search for a sustainable lifestyle and have almost no connection with markets.

The relationship among these three agroecological lines has been highly conflictive, particularly between capitalized and peasant farmers and between movement-oriented and market-oriented producers. In this paper, I examine the three branches of the agroecological movement, showing that (1) despite their significant differences, all of them, though in rather different ways, constitute exercises of countermovement and civic agriculture, and (2) the distinction between the conventionalized and nonconventionalized approaches is blurred and cannot explain the complexity of the strategic practices of at least two of the branches.

\section{Between Personal Commitment and Market Demands: AAOCH and Bío-Bío Orgánico}

AAOCH is a national organization of organic producers whose purposes are to promote agroecological practices, politically represent and lobby for their associated interests, initiate business efforts, promote national and international organic consumption, and safeguard organic standards. Bío-Bío Orgánico represents farmers mostly from the Bío-Bío region as well as from other parts of southern Chile. Many of its members also participate in $\mathrm{AAOCH}$, and the purposes and activities of these two groups overlap, although Bío-Bío Orgánico is distinguished by its largely local nature and has a more political emphasis, taking a public stance and lobbying on issues related to transgenics, seeds, and monoculture practices.

At first glance, the medium-sized, capitalized, market-oriented farmers associated with these organizations seem to constitute a highly conventionalized group that barely represents any form of countermovement against the dominant forms of 
production. These producers are highly oriented to the conventional markets; many of these farmers deal with organic packing agro-industries, mostly of berries, oriented to the Northern organic demand and domestic supermarket chains and health stores oriented to national high-income consumers. They thus reflect the conventional political and economic relationships that are widely described in the literature for farmers and food corporations (Grossman, 1998; Warning \& Key, 2002). In fact, organic packing industries seem to reproduce the same kind of relationship with farmers as conventional packing industries, especially in terms of the power imbalance and monopsonic position of the firm in relation to multiple farmers. In this sense, the capacity of the farmers to negotiate contracts and prices with the firms has been reduced to that of "price takers." Packing firms can be very selective regarding the produce they will accept and are able to refuse loads for reasons that are not always under the producers' control. In some cases, packing firms also play a highly relevant role in supervising the conditions of production, leaving the farmers with little control over the production processes of their own farms. Finally, because the packing companies' organic criteria are usually limited to avoiding the use of certain products (e.g., pesticides, herbicides, and transgenics) rather that promoting agroecological practices, these companies enforce minimal criteria for organic production among their suppliers.

Interestingly, direct supply to educated, highincome urban dwellers by farmers' markets - as is common in the North — is still very limited, as local ferias, or street markets sometimes supplied by farmers, are mostly oriented to lower-income consumers. Therefore, market-oriented organic farmers' production for local markets mostly goes through supermarkets and speciality stores. The relationships of these farmers with supermarket chains are also conflicted. Most individual organic farmers are not able to meet the demands of supermarket chains for a reliable, year-round supply of homogeneous quality. There are, however, some cases in which - by developing an exclusive niche product such as organic herbal teas or organic marmalade — farmers have been able to find shelf space in high-end supermarkets. This niche, of course, offers an important business opportunity, but it is not free of risk; the negotiating capacity of the farmers may be low in relation to giant supermarkets, and the farmers' niche products may experience price competition in the form of premium products from larger, conventional firms that share the same shelf space.

When renegotiating and exercising autonomous forms of power, organic farmers do better than conventional farmers. Given their exclusive produce, some organic farmers can (1) occupy supermarket shelves with their own brands (something that is virtually impossible for conventional farmers), (2) obtain better prices from retailers on the grounds of exclusivity, and (3) develop spaces for direct relationships with consumers through small health and "alternative" stores or by direct supplying. On the international level, organic producers may obtain better prices from packing companies and, more importantly since organic products are still limited in number, it is less likely that buyers will refuse organic produce. In fact, farmers usually say that one of the driving forces behind their shift to organic production is not obtaining price premiums, which they find to be improbable, but ensuring a captive market. Furthermore, although organic packing companies are as intrusive in terms of internal farm management as conventional ones, they also allow and promote several sustainable agricultural practices. For instance, organic packing companies encourage intercropping in between the berries, which allows combining berry production for the international market with more diversified vegetable production for household consumption and domestic sales. These trends require a more careful examination of the fatalist conventionalization thesis.

It is also important to note that most of the interviewed organic farmers indicated a high level of personal commitment to agroecology. Since Chilean organic businesses are still small and do not offer the producers a really important cost benefit, farmers engaging in organic practices do so largely because of a personal commitment and life experience, not because they were encouraged by 
price premiums. One of the most important driving forces for "going organic" is the dramatic personal or family experience of pesticide poisoning. The illness or death of a family member due to agrochemicals constitutes an absolute turning point, a sort of "conversion" to organic farming that includes the choice to not only produce organically for the market, but also to supply a full range of agroecological food for the family diet. This involves complex intrafarm production systems and the development of several informal exchanges with other organic producers. Other farmers go organic as a way to combine a former militancy in left-wing political groups with a newer ecological sensitivity or a personal relationship with the countryside and nature, reflected in statements such as, "I want to cultivate as my father did, with respect for nature." One example of this kind of commitment is the case of a farmer who produces milk in a strictly agroecological way despite the impossibility of obtaining a price premium (in Chile, no brands currently offer organic milk). This farmer sells all his milk to a nonorganic cheese factory at the regular price. According to him, the reason for this apparently anti-economic behavior is that it allows him to obtain organic fertilizer in the form of his cows' manure for his other organic crops, for which he has established a complex system of production and nutrient circulation. Even the manager of the certifying company BCS, an actor that the literature would consider among the most conventionalized ones, has a personal historical involvement with anthroposophy, a philosophical approach related to the permacultural movement. Most farmers consider this personal commitment to be a core of resistance against conventionalization practices as well as a civic exercise.

In this group of market-oriented organic farmers, conventionalized and nonconventionalized practices become blurred. Farmers may produce massive amounts of minimally organic (pesticidefree) berries for packing while engaging in several practices in their fields that go well beyond the minimal certification criteria, performing an ecological embeddedness. As described earlier, they may practice intercropping for both household consumption (a vegetable garden) and for selling in the domestic market (as medicinal herbs); they may produce their own compost rather than buying commercial organic fertilizers; or they may even establish certain organic production measures even though they cannot get a premium price. Therefore, despite documented conventionalization trends, these farmers also show countertrends. Although it is not possible to state that these farmers have developed an actual food community, they do work within an ecological paradigm and attempt to re-localize the food production process. Thus, to dismiss them as conventionalized and minimally organic producers is a gross oversimplification. Instead, we must rethink the ways in which authentic environmental concerns are combined with private farming practices.

\section{Agroecological Peasants and Urban Gardeners: On the Margins of Conventionalization Trends}

A variety of small rural and urban food producers and their producer associations constitute a second branch linked to agroecological practices. These are small-scale producers with little access to national and global markets, an orientation to selfconsumption and local markets, and an instrumental preference for agroecological practices as a way to reduce their production costs. Some of the producer organizations in the region are Cooperativa El Carmen (El Carmen Cooperative), Asociación Comunal de Huertos Orgánicos (Communal Association of Urban Organic Gardens, UCHO), and the local branch of the Asociación Nacional de Mujeres Rurales e Indígenas (National Rural and Indigenous Women's Association, ANAMURI), the main political peasant organization in Chile and one also affiliated with Via Campesina. ${ }^{1}$ These organizations are constituted and led by politically informed, highly active campesinos and campesinas (country people) who do not accept being reduced to the role of mere producers, as evidenced when I

\footnotetext{
${ }^{1}$ Via Campesina in an international peasant movement that brings together 150 local and national organizations of peasants, small, landless, women, and indigenous farmers, as well as agricultural workers from 70 countries. It defends small-scale sustainable agriculture as a way to promote social justice and dignity, opposing corporate-driven agriculture.
} 
unfortunately introduced the leaders of

ANAMURI as the leaders of women agricultural producers during a food sovereignty meeting that I was moderating. The women quickly clarified their position: "First of all, we are not producers, our lives are not oriented toward producing for the urban market; we are campesinas [country women]; we are the curators of the countryside, its landscape, its environment, its people."

These organizations became involved with agroecological practices through their relationships with three traditional NGOs that have been working in the Bío-Bío region for several decades: CET Yumbel, CET Sur, and Trabajo para un Hermano (Work for a Brother, TPH). The work of these NGOs goes well beyond agriculture and organic production, promoting a wide range of sociably sustainable and environmentally appropriate practices such as solidarity economy, food sovereignty, bioconstruction, low-cost alternative energy, and sustainable forestry, among both rural and urban dwellers. The work of these NGOs is infused with a deep sense of place in terms of caring for local people, economies, landscapes, and nature.

Unlike the highly informed, ideological commitment shown by the leaders of El Carmen and ANAMURI, the peasant constituency of these organizations is very pragmatic, grounded in a concrete concern for their place and livelihood rather than by a more ideological commitment to agroecology. In fact, these peasant groups are oriented mostly to recovering and revaluing traditional intrafarming practices that they know well (e.g., saving seeds, preparing natural fertilizers, and managing pests with natural methods), mainly as a means of substituting expensive and standardized agricultural inputs with site-specific technologies using cheaper supplies prepared on the farm. Therefore, the ecological discourse of these NGOs is articulated by the pragmatic need of the peasants to lower their costs and their identity needs for recognizing traditional know-how.

Urban producers grouped in the UCHO develop intensive gardens in small backyards and abandoned public spaces. They are motivated by the desire to improve their families' diets with highquality products, revalue the know-how of their peasant family background, and develop a small local trade within the neighborhood to complement their livelihood strategies. To this end, they organize in associations - actually, localized food communities - that allow them to share labor and knowledge as well as seeds and surplus produce.

For the constituency of these rural and urban organizations, agroecological practices clearly respond to more than political and ethical options, instead articulating broader livelihood issues. Thus producers go well beyond minimally organic criteria to engage in a broad range of ecological - and economical - practices, such as saving rainwater for irrigation, using bioconstruction, and exchanging seeds. In this sense, their evaluation of the agroecological knowledge they obtained from the NGOs does not depend on whether it is correct or incorrect from an environmental point of view, but on how it contributes to maintaining the land entrusted to them as campesinos, the quality of their production, their cost structure, and the health of their family.

These producers are mostly oriented to household consumption and local and direct markets (ferias and neighborhood trade). Therefore, they are located on the margins of formal markets and totally outside the sphere of supermarket chains or export companies. Agroecological production does not offer them a premium price, but generally lowers their costs through the household production of seeds, fertilizers, and pest control. Some of their successful commercialization strategies represent good examples of alternative, locally based, short commodity chains. There are some cases of "peasant markets" located not only in the area's main cities (Chillán and Concepción) but also in smaller towns, oriented to lower-income consumers. There is very limited participation, however, in the main peasant market in the area, Feria de Collao, in the city of Concepción, which is supplied mostly by nonagroecological peasants and farmers. More important are the personal distribution networks within urban neighborhoods through which peasants meet all the vegetable needs of nearby towns. 
The trefkintus (the bartering of seeds, early plants, and produce) are more than mere occasions of exchange; they have become symbolic places of where sabores y saberes — tastes and knowledge meet. In fact, agricultural exchanges are just one part of a broad set of activities ranging from music to communal meals, a sort of coexistence stripped of elitism. After the earthquake of February 2010 in this area, these farmers started a direct supply chain with some of the most affected coastal communities. There has also been an attempt, although it is not yet fully implemented, to connect the El Carmen Cooperative with urban trade unions in the largest nearby cities through direct supplying. All these initiatives constitute experiments with civic economic relationships between producers and consumers.

These forms of commercialization, which do not involve premium prices and are not oriented to high-end markets, do not enter into the logic of certification regimes for several reasons. First, there is no price reward for an organic seal on the local and popular markets in which this produce is commercialized. Second, peasants and urban producers have a hard time complying with the bureaucratic requirements and economic resources needed for a certification process. Finally, in practice, the organic criteria are relatively minimal in relation to the actual practices of the producers. In fact, the NGOs that support those producers and the leaders of their organizations are sharply critical of certification regimes and refuse even to consider the collective options offered by certifiers.

Both the interconnection between livelihood economic strategies and agroecological practices as well as the refusal to participate in certification regimes make these groups less prone to the conventionalization trends described in the literature. On the other hand, because the commitment to agroecological practices among these producers is more strategic than ideological, they may be prone to return to conventional agriculture when faced with a different cost-yield evaluation (e.g., cheaper agrochemicals). Despite that, their commitment to safeguarding traditional practices against the encroachment of dominant relations of production in and of itself constitutes a political-ecological practice in which livelihood interests and civic options become blurred. It is safe to say that these food communities embody the three embeddednesss described for civic agriculture: an endeddedment in nature, as they are highly respectful of the soil, water and seeds they take care off as campesinos and campesinas, and embeddedness in place, as local resources, market, knowledge, technologies, and products are core to their practices; and finally an embeddedness on the actual building of a food community.

\section{Permaculture Movement}

Finally, the agroecological movements in the region also include a smaller branch that ascribes to permaculture principles. This movement is mainly composed of two collective actors: (1) a traditional, elite farm family that decided to withdraw from conventional practices and establish both a demonstration permaculture farm oriented toward self-sufficiency and an eco-school to teach permaculture practices to the general public and neighboring peasants; and (2) the Chilean Permaculture Institute (ICP), formed by a network mostly made up of university students, that practices urban agriculture mainly following the principles of permaculture, and promotes urban ecology and bioconstruction through workshops and other activities. The works of the ICP were especially important after the Concepción earthquake as it promoted bioconstruction to improve the quality of the emergency shelters provided by the government. The scale and economic significance of both groups are rather small, and they are only relevant for their ideological impact and demonstrative effect. They are not business-oriented; in fact, they attempt to reach some sort of self-sufficiency without producing for trade, explicitly constituting an attempt at building a food community in opposition to market relationships. Therefore, neither group is prone to the described conventionalization trends. The same self-sufficiency that prevents them from conventionalization raises questions about their citizenship commitment, as selfsufficiency seems unsocial. On the other hand, their strong ideological background and constant 
activities to spread permacultural principles in both rural and urban areas restores to them the social dimension denied by their self-sufficiency.

\section{Conventionalization Trends or Civic Agriculture?}

This review of the three branches within the agroecological movement of the Bío-Bío region raises several considerations regarding the conventionalization hypothesis as seen from a Southern country. First, in the context of free-market, globally oriented, agrarian economies, there are real forces that push conventionalization processes among organic producers, including the highly conventional practices developed by organic packing companies (whose production relations do not differ substantially from nonorganic ones) and the dissemination of their minimal organic criteria. In the same vein, the pressure for large-scale production, lower costs, and standardization brought to bear by supermarket chains is also a relevant trend. Finally, certifiers use minimal criteria and unintentionally select large producers capable of meeting the certifiers' bureaucratic requirements.

However, as described, not all agroecological producers are affected by those pressures. In particular, small peasant producers and urban agriculture producers are not oriented to the mainstream food market and thus do not interact with packing firms, supermarkets, or certifiers, and so are not vulnerable to the previously described conventionalization pressures. Moreover, for most such producers, agroecological practices are a matter of ethical principles as well as of highly economic practices that allow them to lower their production costs and diversify their livelihoods. In this sense, these producers perform a political exercise that not only defends an abstract idea of environment, but also addresses place-based and very personal and political issues.

Several countertrends can also be found among market-oriented organic farmers. First, they have a strong ideological commitment to agroecological practices and thus go beyond the demands for certification. At the same time, as in the case of the peasants, these farmers use agroecological practices such as intercropping in order to complement cash crops with household consumption and domestic markets and to lower their production costs. In this sense, small and medium-sized market-oriented producers do not obey the dualistic segmentation described in the literature, but instead follow a mixed trend that includes a variety of practices. Particularly, this trend combines some highly conventionalized production for external markets with agroecological practices for domestic markets, where organic producers also embody political options for civic agriculture.

In this sense, it is important to relate the discussion of citizenship to the sphere of production rather than that of consumption. If citizenship refers to a notion of civic debate and coordinated action, then committed producers - as compared with informed consumers - are closer to citizenship. Whereas producers intertwine their whole livelihood strategies with sustainability options, consumers rarely go beyond shopping responsibility, expecting producers to do the actual "work" for them.

This case also reminds us of the complexity, diversity, and contradictory nature of Polanyian countermovements. According to Polanyi, society attempts to protect itself from the "satanic mill" unleashed by the self-regulated market, but no single unified countermovement exists, nor does one class lead such a movement from an absolute point of view. On the contrary, Polanyi describes how several groups that are affected by selfregulating markets in different ways, raise different protective measures to address their own affected interests and, in doing so, temporarily represent the general interest of society. In his analysis, even landlord classes may take the progressive role of defending land from the consequences of its commoditization. This analysis is appealing since it deessentializes the question of political action, acknowledging the potential of progressive action by an unlikely actor and allowing for the possibility of diverse political articulations. In this case, small peasants as well as several actors from different backgrounds (from medium-sized, businessoriented farmers to students and urban dwellers) 
react against corporate-dominated agriculture and attempt to raise a civic countertrend from their own realm. These citizenship exercises are intertwined with the everyday practice of working, producing food, and caring for the small plots of land and water that they feel have been entrusted to them.

\section{References}

Altieri, M. (1998). Ecological impacts of industrial agriculture and the possibilities for truly sustainable farming. Monthly Review, 50(3), 60-71.

Bacon, C. (2005). Confronting the coffee crisis: Can fair trade, organic and specialty coffees reduce smallscale farmer vulnerability in Northern Nicaragua? World Development, 33(3), 497-511. doi:10.1016/j.worlddev.2004.10.002

Barndt, D. (2002). Tangled routes: Women, work and globalization on the tomato trail. Aurora, Ontario: Garamond Press.

Buck, D., Getz, C., \& Guthman, J. (1997). From farm to table: The organic vegetable commodity chain of northern California. Sociologia Ruralis, 37(1), 3-20. doi:10.1111/1467-9523.00033

Instituto Nacional de Estadísticas. Censo Agropecuario, 2006-2007. http://www.censoagropecuario.cl

DeLind, L. D. (2002). Place, work and civic agriculture: Common fields for cultivation. Agriculture and Human V alues, 19(3), 217-224. doi:10.1023/A:1019994728252

DeLind, L., \& Bingen, J. (2008). Place and civic culture: Re-thinking the context for local agriculture. Journal of Agricultural and Environmental Ethics, 21(2), 127151. doi:10.1007/s10806-007-9066-5

Dowler, E. (2008).Food and health inequalities: the challenge for sustaining just consumption. Local Environment: The International Journal of Justice and Sustainability, 13(8): 759-772.

FitzSimmons, M. (1997). Commentary on part II: Regions in global context restructuring, industry, and regional dynamics. In D. Goodman \& M. Watts (Eds.), Globalising Food: Agrarian Questions and Restructuring (pp. 115-120). London: Routledge.

Friedmann, H. (1994). Distance and durability: Shaky foundation of the world food economy. In P. McMichael (Ed.), The Global Restructuring of AgroFood Systems (pp. 258-276). Ithaca, NY: Cornell University Press.

Gómez Tovar, L., Martin, L., Angel Gómez Cruz, M., \& Mutersbaugh, T. (2005). Certified organic agriculture in Mexico: Market connections and certification practices in large and small producers. Journal of Rural Studies, 21(4), 461-474.

González, A. A., \& Nigh, R. (2005). Smallholder participation and certification of organic farm products in Mexico. Journal of Rural Studies, 21(4), 449-460. doi:10.1016/j.jrurstud.2005.08.004

Goodman, D. (2005). Organic and conventional agriculture: Materializing discourse and agroecological managerialism. Agriculture and Human Values 17(3), 215-219. doi:10.1023/A:1007650924982

Grossman, L. (1998). The political ecology of bananas: Contract farming, peasants, and agrarian change in the Eastern Caribbean. Chapel Hill: University of North Carolina Press. doi:10.1525/cag.1999.21.2.36

Guthman, J. (2004a). Room for manoeuvre? (In)organic agribusiness in California. In K. Jansen \& S. Vellema (Eds.), Agribusiness and Society: Corporate Reponses to Environmentalism, Market Opportunities and Public Regulation (pp. 114-142). New York: Zed Books.

Guthman, J. (2004b). The trouble with "organic lite" in California: A rejoinder to the "conventionalisation" debate. Sociologia Ruralis 44(3): 301-316. doi:10.1111/j.1467-9523.2004.00277.x

Jarosz, L., \& Qazi, J. (2000). The geography of Washington's world apple: Global expressions in a local landscape. Journal of Rural Studies 16(1), 1-11. doi:10.1016/S0743-0167(99)00028-5

Klonsky, K. (2000). Forces impacting the production of organic foods. Agriculture and Human Values 17, 233-243. doi:10.1023/A:1007655312687

Kneen, B. (1999). Restructuring food for corporate profit: The corporate genetics of Cargill and Monsanto. Agriculture and Human Values, 16(2), 161167. doi:10.1023/A:1007586710282

Kojima, A. (2010). Responsibility or right to eat well? Food education (shokuiku) campaign in Japan. Paper presented at the annual meeting of the American Sociological Association Annual Meeting, Hilton Atlanta and Atlanta Marriott Marquis, Atlanta. Retrieved from http://www.allacademic.com/ meta/p412336 index.html

Leahy, T. (2004). Food, society and the environment. In J. Germov \& L. Williams (Eds.), A Sociology of Food and Nutrition: The Social Appetite (pp. 52-76). South Melbourne: Oxford University Press.

Lyson, T. A. (2000). Moving toward organic agriculture. Choices (3), 42-45. 
Lyson, T. A. (2004). Civic agriculture: Reconnecting farm, food, and community. Lebanon, NH: University Press of New England.

Lyson, T., \& Guptill, A. (2004). Commodity agriculture, civic agriculture and the future of U.S. farming. Rural Sociology 69(3), 370-385. doi:10.1526/0036011041730464

Muradian, R., \& Pelupessy, W. (2005). Governing the coffee chain: The role of voluntary regulatory systems. World Development 33(12), 2029-2044. doi:10.1016/j.worlddev.2005.06.007

Polanyi, K. (2001). The great transformation. The political and economic origins of our time. Boston, MA: Beacon Press.

Pratt, J. (2009). Incorporation and resistance: Analytical issues in the conventionalization debate and alternative food chains. Journal of Agrarian Change 9(2), 155-174. doi:10.1111/j.1471-0366.2009.00190.x

Raynolds, L. (2000). Re-embedding global agriculture: The international organic and fair trade movements. Agriculture and Human Values, 17(3), 297-309. doi:10.1023/A:1007608805843
Raynolds, L. (2003). The globalization of organic agrofood networks. World Development, 32(5), 725-743. doi:10.1016/j.worlddev.2003.11.008

Rosin, C., \& Campbell, H. (2009). Beyond bifurcation: Examining the conventions of organic agriculture in New Zealand. Journal of Rural Studies, 25(1): 3547. doi:10.1016/j.jrurstud.2008.05.002

Seyfang, G. (2005). Shopping for sustainability: Can sustainable consumption promote ecological citizenship? Environmental Politics, 14(2): 290-306. doi:10.1080/09644010500055209

Seyfang, G. (2006). Ecological citizenship and sustainable consumption: Examining local organic food networks. Journal of Rural Studies, 22(4), 383-395. doi:10.1016/j.jrurstud.2006.01.003

Warning, M., \& Key, N. (2002). The social performance and distributional consequences of contract farming: An equilibrium analysis of the Arachide de Bouche program in Senegal. World Development, 30(2), 255-263. doi:10.1016/S0305-750X(01)00104-8 